\title{
A Stochastic Frontier Approach for Measuring Technical Efficiency of Catfish Production in Delta State; Nigeria
}

\author{
Enimu Solomon PhD*, Edet Onome George \\ Department of Agricultural Economics; University of Calabar; Cross River State; Calabar; Nigeria
}

\section{*Corresponding Author}

Enimu Solomon PhD

\section{Article History}

Received: 06.09.2019

Accepted: 25.09 .2019

Published: 02.11.2019

\begin{abstract}
The study analyzed the economics of catfish production in Delta State Nigeria. The multi-stage random sampling technique was used in selecting 700 catfish farmers from the study area using the proportionate sampling method. Primary data were collected through the use of questionnaires and group discussions. Data were analyzed using budgeting techniques and the stochastic frontier production function. The result of socio-economic characteristics of the respondents indicate that majority of the farmers were within the age range of 20-39 years; male; had formal education and married with a household size of 1-5 persons. Catfish production was found to be a profitable business in the study area with a net farm income of $402 ; 654$ and rate of return on investment of $\mathrm{A} 1.48$ and a gross ratio of $\mathrm{A} 1.67$ for every naira spent on production. The mean technical efficiency was $57 \%$. Findings further revealed that none of the sampled catfish farmers reached the frontier threshold. However; variables included in the model for the efficiency effects were stocking density; Labour; feeds; drugs and fingerlings. The parameters of the stochastic frontier production function were estimated simultaneously with those of the inefficiency effects. It is therefore recommended that extension workers should intensify organization of training; workshops and seminars for catfish farmers on improved methods and technology; cost of farm implements and feeds should be subsidized to ease the risk of catfish farming and young unemployed youths should be encouraged to participate in the catfish business so as to generate employment and income towards sustainable rural development.
\end{abstract}

Keywords: Profitability; Catfish; Production; Delta State.

\section{INTRODUCTION}

The increase in human population and reports of large numbers of people undernourished or starving in developing countries has made the need for food production a major worldwide issue of concern. Throughout the centuries fish has been an important component of human diet in many parts of the world. Fish catches increased rapidly over the past hundred years due to improved technology which provided more powerful fishing engines and equipment. This led to over fishing and causes a worldwide decrease in wild fishing stocks and the need to increase fish production by fish farming (aquaculture)[1].

Nigerians are high fish consumers and offer the largest market for fish and fisheries products in Africa. Fish farming has thus become an important venture in the quest for food security and eradication of malnutrition especially among infants [2]. With an annual fish demand in the country of about 2.66 million tones and a paltry domestic production of about 780; 000 tones; the demand-supply gap stands at a staggering 1.8 million tones. Despite the popularity of fish farming in Nigeria; the fish farming industry can best be described as being at the infant stage when compared to the large market potential for its production and marketing [3]. The major protein sources in the country include cattle; goats; sheep; poultry and fish. Out of these sources fish and fish products provide more than $60 \%$ of the total protein intake in the adults especially in the rural areas [4]. Therefore the importance of fishing industry (catfish production) to the sustainability of animal protein supply in the country cannot be overemphasized. Regrettably the supply of food fish has been on the decline from the country's major source of food fish; the artisanal fisheries form $90 \%$ in 1990 down to $40 \%$ in 2006 [5].

In as much as fish especially the catfish species is widely consumed in Nigeria. This has prompted the Federal Government of Nigeria to package the Presidential initiative on fisheries and aquaculture development in 2003 to provide financial and technical

Copyright @ 2019: This is an open-access article distributed under the terms of the Creative Commons Attribution license which permits unrestricted use, distribution, and reproduction in any medium for non commercial use (NonCommercial, or CC-BY-NC) provided the original author and source are credited. 
assistance to government programmes and projects encouraging fish production. Hence the Nigeria government adopted different programmes and policies aimed at raising productivity and efficiency of these production. Although aquaculture in Nigeria has the potential for satisfying the increased demand for protein and has been experiencing unprecedented growth during the last decade; question remains regarding the sustainable development of the industry [6].

Statistical survey has shown that the demand for fish in Nigeria exceeds supply and the domestic production is very low despite the abundant water resources and available manpower. The implication of this is that the national demand has not been met. The above scenario provides the enabler for this study aimed at examining the profitability and efficiency of catfish production in Delta State; Nigeria with a view to bridging the current gap between the demand and supply.

\section{Objectives of the Study}

The main objective of the study is to analyze the profitability and technical efficiency of catfish production in Delta State; Nigeria. The specific objectives include:

- Describe the socio-economic characteristics of catfish farmers

- Evaluate the profitability of catfish production in the state

- Determine the level of technical efficiency of catfish production in the study area

- Make policy recommendations based on the findings of this study.

\section{Hypothesis of the study}

The study was guided by the following hypothesis

- No significant relationship exists between the selected socio-economic/production variables and the catfish farmers output and technical efficiency.

\section{Methods}

\section{Study area; sampling and data collection}

This study was carried out in Delta State which is located in the South-South of Nigeria and one of the 36 States constituting the Nigeria Federation. The State was created in August 27, 1991 out of the defunct Bendel State. The State comprises Twenty-five (25) Local Government Areas (LGAs). Delta State is located between longitude $5^{0} 00^{1}$ and $6^{0} 45^{1}$ East and latitude $5^{0} 00^{1}$ and $6^{0} 30^{1}$ North. It is bounded on the North by Edo State, on the Northwest by Ondo State, Anambra State on the East and Bayelsa State on the South East. On the Southern flank is the Bight of Benin, which covers approximately 160 kilometers of the State's coastline [7]. The 2006 population census puts the population of Delta State at 4,098,391 made up of 2,074,306 males and 2,024,085 females, with a land area of $17,011 \mathrm{sq}$ kilometres [8]

The State has a tropical climate marked by two distinct seasons: the dry and rainy seasons. The dry season occurs between November and April, while the raining season begins in April and last till October. There exist a brief dry spell in August commonly referred to as 'August break'. The average annual rainfall is about $2667 \mathrm{~mm}$ in the coastal areas and $1905 \mathrm{~mm}$ in the Northern areas. Rainfall is heaviest in July. Delta State has a high temperature ranging between $29^{\circ} \mathrm{C}$ and $44{ }^{\circ} \mathrm{C}$ with an average of $30^{\circ} \mathrm{C}$ [9]. The vegetation consists of the mangrove swamp along the coastal areas and their thick rain forest in the middle and the Savannah in the North. The geographical description of the state favours fish farming.

\section{Sampling procedure and data collection/analysis}

The multi-stage random sampling technique was used to select respondents. Stage one involve a purposive selection of the three agricultural zones based on the ADP zoning structure; stage two involves a random sampling of fourteen (14) local government areas from the twenty-five using proportionate sampling method. Stage three involves a random sampling of five (5) communities each from the LGAs while stage four involves a random selection of ten (10) catfish farmers from of the communities. A total of seven hundred (700) catfish farmers were selected for the study.

The study was both primary and secondary data. Primary data was collected using well-structured questionnaire complimented with group discussion to elicit information from farmers and were designed in line with the objectives of the study while secondary data were sourced from relevant materials published and unpublished. Data collected were analyzed using both descriptive and inferential statistical tools such as table; percentage; frequency; mean; cost and returns analysis and stochastic frontier production technique.

\section{The empirical model}

\section{Cost and Returns Analysis}

Cost and returns analysis investigates the profitability of the business; it was used to determine the productivity of catfish production. The budgeting technique employed was the net farm income and profitability ratio which were used to examine the cost 
and returns of catfish farming in the study area. The difference between the Gross Revenue (GR) and the Total Cost (TC) gives the Net Revenue (NR). Net Farm Income is expressed as:

$$
\mathrm{NFI}=\mathrm{GR}-\mathrm{TC}
$$

Where

$\mathrm{NFI}=$ Net farm income (naira)

$T C=(T V C+T F C)=P x \cdot X$

$\mathrm{GR}=$ Gross revenue $=\mathrm{Py} . \mathrm{Y}$ (naira)

$P y=$ Unit price of output (naira)

$Y=$ Quantity of output (naira)

$P x=$ Unit price of input (naira)

$X=$ Quantity of input (naira)

$\mathrm{TC}=$ Total cost (naira)

TFC $=$ Total fixed cost (naira)

TVC $=$ Total variable cost (naira)

The performance and economic worth of the catfish farmers can be determined by the use of Expense Structure Ratio (ESR); Benefit Cost Ratio (BCR); Gross Margin Ratio (GMR) and Rate of Return (ROR).

\section{The Stochastic Frontier Production Model}

Stochastic frontier production model was used for estimating technical efficiency of catfish production. It is estimated as follows

Where

$$
\ln Y=\beta_{0}+\beta_{1} \ln X_{1}+\beta_{2} \ln X_{2}+\beta_{3} \ln X_{3}+\beta_{4} \ln X_{4}+\beta_{5} \ln X_{5}+(V i-U i)
$$

In = Natural logarithm.

$\beta_{0}=$ Constant term

$\beta \mathrm{i}-\beta_{5}=$ Regression coefficient

$\mathrm{Y}=$ Output of catfish $(\mathrm{kg})$

$\mathrm{X}_{1}=$ Stocking density (No.)

$X_{2}=$ Total labour used (man days)

$X_{3}=$ Quantity of feeds $(\mathrm{kg})$

$X_{4}=$ Quantity of drugs $(\mathrm{mg})$

$X_{5}=$ Quantity of fingerlings $(\mathrm{kg})$

$\mathrm{Vi}=$ Random variability in the production that cannot be influenced by the farmer

$\mathrm{Ui}=$ Deviation from maximum potential output attributable to technically inefficiency.

The determinant of technical inefficiency is defined by:

$-U i=\delta_{0}+\delta_{1} Z_{1}+\delta_{2} Z_{2}+\delta_{3} Z_{3}+\delta_{4} Z_{4}+\delta_{5} Z_{5}+\delta_{6} Z_{6}+\delta_{7} Z_{7}+\delta_{8} Z_{8}$

Where

$\mathrm{Ui}=$ Inefficiency effects

$\delta_{0}=$ Constant

$\delta_{1}-\delta_{8}=$ Parameters to be estimated

$Z_{1}=$ Farmers age in years

$Z_{2}=$ Farming experience in years

$Z_{3}=$ Level of education in years

$Z_{4}=$ Cooperative membership (years)

$Z_{5}=$ Amount of credit obtained (naira)

$Z_{6}=$ Extension contact in the production year in numbers of visit

$Z_{7}=$ Sex of farmer in dummy ( $1=$ male and $0=$ female $)$

$Z_{8}=$ Household size in number of persons in the house.

\section{Results And Discussion}

\section{Socio-economic characteristics of respondents}

Results from table 1 indicated that majority of the catfish farmers were within the ages of $20-39$ years which represent about $45.7 \%$ of the total number of the selected farmers with a. 
Table-1: Socio-economic characteristics of catfish farmers

\begin{tabular}{|c|c|c|}
\hline Variables & Frequency & Percentage \\
\hline \multicolumn{3}{|l|}{ Age } \\
\hline Less than 20 & 53 & 7.6 \\
\hline $20-39$ & 320 & 45.7 \\
\hline $40-59$ & 242 & 34.6 \\
\hline 60 and above & 85 & 12.1 \\
\hline Mean & 38 & \\
\hline \multicolumn{3}{|l|}{ Sex } \\
\hline Male & 439 & 62.7 \\
\hline Female & 261 & 37.3 \\
\hline \multicolumn{3}{|l|}{ Educational level } \\
\hline No formal education & 78 & 11.1 \\
\hline Formal education & 622 & 88.9 \\
\hline \multicolumn{3}{|l|}{ Marital status } \\
\hline Married & 501 & 71.6 \\
\hline Single & 199 & 28.4 \\
\hline \multicolumn{3}{|l|}{ Household size } \\
\hline $1-5$ & 437 & 62.4 \\
\hline $6-10$ & 186 & 26.6 \\
\hline 11 and above & 77 & 11.0 \\
\hline Mean & 6 & \\
\hline \multicolumn{3}{|l|}{ Types of labour } \\
\hline Family & 603 & 86.1 \\
\hline Hired & 97 & 13.9 \\
\hline \multicolumn{3}{|l|}{ Fishing experience } \\
\hline $1-5$ & 493 & 70.4 \\
\hline $6-10$ & 181 & 28.9 \\
\hline 11 and above & 26 & 3.7 \\
\hline Mean & 8 & \\
\hline \multicolumn{3}{|l|}{ Amount borrowed } \\
\hline Less than $100 ; 000$ & 337 & 48.1 \\
\hline $100 ; 001-500 ; 000$ & 264 & 37.7 \\
\hline Above 500;000 & 99 & 14.2 \\
\hline Mean & $255 ; 540$ & \\
\hline \multicolumn{3}{|c|}{ Membership of cooperative } \\
\hline Yes & 538 & 76.9 \\
\hline No & 162 & 23.1 \\
\hline \multicolumn{3}{|l|}{ Management system } \\
\hline Earthen ponds & 482 & 68.9 \\
\hline Concrete ponds & 218 & 31.1 \\
\hline Total & 700 & 100 \\
\hline
\end{tabular}

Source: field survey data; 2018.

Mean age of 38 years. This age bracket is a productive age which portends better future for catfish production. The table reveals that $62.7 \%$ of the respondents were males while $37.3 \%$ were females. The dominance of men in catfish production was due to the fact that women are involve more in crop production and produce marketing. The finding conforms to work by Esu; Asa and Iniedu [10] who reported that catfish production is dominated by males.

Majority of the respondents $88.9 \%$ has attained various levels of formal education while only $11.1 \%$ had informal education. The result shows that most of the farmers are literate and understand catfish management and production techniques. The table also revealed that $71.6 \%$ of the farmers are married while $28.4 \%$ were single. Based on household size; $62.4 \%$ of the farmers had between $1-5$ persons with a mean household size at 6 persons; the relatively low household size among the catfish farmers can be attributed to their level of education which is high relatively. Adebayo [11] opined that family can serve as source of free and cheap labour. 
Majority of the respondents $70.4 \%$ had fishing experience ranging between 1-5 years with a mean fishing experience at 8 years. This may be attributed to the fact that fish farming is a relatively new business venture compared to the normal wild artisanal fishing in natural fishing water. Nwiro [3] was of the opinion that the ability to manage fish pond efficiently depends on the experience and this is directly related to the total productivity of the farm. The table further revealed that $48.1 \%$ of the farmers borrowed less than $\mathrm{N} 100 ; 000$ to run the farm business while $37.7 \%$ borrowed between N100; 000-N500; 000. The mean amount borrowed was N255; 540. Majority of the respondents $76.9 \%$ are members of cooperative societies while $23.1 \%$ do not belong to cooperatives. The table further revealed that $68.9 \%$ of the farmers used earthen pond while $31.1 \%$ uses concrete ponds. This result agrees with Asa and Obinaju [10] who stated that majority of catfish farmers in the Niger delta region use earthen ponds for catfish production.

\section{Profitability analysis of catfish farming}

The profitability of catfish production is ascertained using the cost and returns analysis. The table 2 reveals that variable costs constitute $68.3 \%$ of the total cost of catfish production while fixed costs accounted for $31.7 \%$. The cost of pond construction $85.3 \%$ was the major fixed cost component while the cost of pumping machine stood at $14.7 \%$. Catfish feeds constitute the major variable cost at $65.1 \%$ of the total variable cost of the respondents while the cost of fingerlings and labour stood at $15 \%$ and $13.8 \%$ respectively as major variable cost. The table indicates that the total cost of catfish production was N832;850 and the total revenue of $\mathrm{N} 1 ; 235 ; 504$ was realized from the sales of harvested catfish making a net income of N402;654.

Table-2: Cost and return analysis of catfish production (N/ 1000kg/hat)

\begin{tabular}{|l|l|l|}
\hline Variables & Cost (N/1000kg/hat) & Percentage (\%) \\
\hline a) variable cost: & & \\
\hline Catfish feeds & $370 ; 000$ & 65.1 \\
\hline Drugs & $23 ; 500$ & 4.1 \\
\hline Liming materials & $11 ; 350$ & 2.0 \\
\hline Labour (man day) & $78 ; 350$ & 13.8 \\
\hline Fingerlings & $85 ; 400$ & 15.0 \\
\hline Total variable cost (TVC) & $\mathbf{5 6 8 ; 6 0 0}$ & 100 \\
\hline b) Fixed cost & & \\
\hline Pond construction & $225 ; 500$ & 85.3 \\
\hline Pumping machine & $38 ; 750$ & 14.7 \\
\hline Total fixed cost (TFC) & $\mathbf{2 6 4 ; 2 5 0}$ & 100 \\
\hline Total cost (TVC + TFC) & $\mathbf{8 3 2 ; 8 5 0}$ & \\
\hline c) Revenue (TR) & $\mathbf{1 ; 2 3 5 ; 5 0 4}$ & \\
\hline d) Net farm income (NFI) & $\mathbf{4 0 2 ; 6 5 4}$ & \\
\hline e) Rate of return on investment (NFI /TC) & $\mathbf{0 . 4 8}$ & \\
\hline f) Expense structure ratio (FC/TC) & $\mathbf{0 . 3 2}$ & \\
\hline g) Gross ratio (TC/TR) & $\mathbf{0 . 6 7}$ & \\
\hline
\end{tabular}

Source: field survey data; 2018.

The cost and return analysis showed that catfish production is profitable in the study area. The findings conform to Asa and Obinaju [10] and Ohen and Abang [1] who reported profitability of catfish production in Akwa-lbom and River State respectively. The benefit cost ratio value of $(1: 48)$ implies that every N1.00 invested in catfish production will yield N1.48. Since the ratio is greater than one; it shows that the enterprise is profitable. This index in percentage is the rate of return on investment; it means that for very N1.00 invested in catfish production; $48 \%$ is made as profit. The value of the expense structure ratio is 0.32 which implies that about $32 \%$ of the total cost of production is made up of fixed cost. This makes the business worthwhile since increase in the production with variable cost will increase the total revenue leaving the fixed cost unchanged. The gross ratio of 0.67 indicates that from every $\mathrm{N} 1.00$ returns to the enterprise; $67 \mathrm{~K}$ is being spent. Based on the above analysis; it obvious that catfish production enterprise is a profitable venture in Delta State that should be encouraged.

\section{Technical efficiency of catfish production}

The model specified was estimated by the maximum likelihood (ML) method using Frontier 4.1 software developed by Coelli [12]. The ML estimates and inefficiency determinants of the frontier are presented in table 3 . The study revealed that the generalized log likelihood function was -63.247. The log likelihood function implies that inefficiency exist in the data set. The log likelihood ratio maximizes the joint densities in the estimated model. Thus; the functional form that is Cobb-Douglas used in the estimation is an adequate representation of the data. The value of gamma $(\gamma)$ is estimated to be $74 \%$ and was significant at $(p<0.01)$ level of probability. This is consistent with the theory that true $\gamma$-value should be greater than zero. This implies that $74 \%$ of random variation in the output of the catfish farmers was due to the farmers' inefficiency. 
Table-3: Maximum likelihood estimates of the stochastic frontier production function $(\mathrm{N}=700)$

\begin{tabular}{|l|l|l|l|}
\hline Variables & Coefficients & Standard error & T - value \\
\hline Production variables & & & \\
\hline Constant & 7.432 & 3.325 & $12.171 \times \times x$ \\
\hline Stocking density & -0.215 & 0.347 & $6.837 \times x x$ \\
\hline Labour & 0.633 & 0.726 & $3.148 \times x x$ \\
\hline Feeds & 0.438 & 0.341 & $8.315 \times x x$ \\
\hline Drugs & 0.324 & 2.343 & 0.321 \\
\hline Fingerlings & -0.323 & 0.457 & $5.279 \times x x$ \\
\hline Inefficiency variables & & & \\
\hline Constant & 1.342 & 4.382 & $9.370 \times x x$ \\
\hline Age & 0.314 & 0.007 & 0.628 \\
\hline Fishing experience & -0.475 & 0.864 & $2.582 \times x$ \\
\hline Educational level & -0.583 & 0.633 & $3.241 \times x$ \\
\hline Cooperative membership & 0.349 & 0.109 & 0.833 \\
\hline Amount borrowed & 0.784 & 0.304 & $4.314 \times x x$ \\
\hline Extension service & $-0.539 \mathrm{E}-05$ & $0.834 \mathrm{E} .06$ & $3.817 \times x$ \\
\hline Sex & -0.684 & 0.872 & 0.387 \\
\hline Household size & -0.728 & 0.537 & $5.042 \times \times x$ \\
\hline Diagnostic parameters & & & \\
\hline Sigma squared & 0.428 & 0.053 & $6.243 \times x x$ \\
\hline Gamma & 0.737 & 0.237 & $2.751 \times x$ \\
\hline Log likelihood & -63.247 & & \\
\hline Mean & 0.568 & & \\
\hline
\end{tabular}

$x x x ; x x ; x$ means significant at 1; 5 and 10\% probability level; respectively; Source: computation from field survey data; 2018.

Reducing the influence of the effects of $y$ will greatly enhance the technical efficiency of the farmers and improve their output. The value of sigma squared $(\sigma)$ was significantly different from the zero level of probability. This indicates a good fit and correctness of the specified distributional assumptions of the composite error term. This means that the inefficiency effects make significant contribution to the technical inefficiency of catfish farmers.

However; the estimated coefficients of the parameters of production function (labour; feeds and fingerlings) were positive while stocking density was negative and significant at $1 \%$ level of probability and therefore play a vital role in catfish production in delta state. The average technical efficiency for the farmers was 0.57 implying that; on the average; the respondent are able to obtain $57 \%$ of potential output from given utilization of production inputs. This gives $43 \%$ unused resource efficiency level on the short-run.

The estimated coefficient of stocking density $(-0.215)$ implies that this variable was negatively related to output and was statistically significant at $1 \%$ probability level. This suggests that one percent increase in the number of fish $/ \mathrm{m}^{2}$ will decrease their output by 0.215 percent. Hence a moderate stocking density is required to improve output because higher stocking capacities reduces water volume/space ratio leading to cannibalism and low output due to struggles for feed. This findings contrast work by Emokaro and Ekunwe [13] and Adulrahman et al. [14]; who reported a positive relationship between stocking density and catfish output.

The estimated coefficient of labour (0.633) means that labour was positively related to output of catfish farmers in the study area and was statistically significant at $1 \%$ probability level. This implies that one percent increase in labour will increase the output of catfish farmers by 0.633 percent. This finding conforms to Ohen and Abang [1]; who reported a positive and significant relationship between labour and catfish output in River State.

Feeds with estimated coefficient (0.438) are positively related and significant at $1 \%$ level of probability. This implies that the quantity feeds given to catfish had a direct relationship with output and that one percent increase in the quantity of feeds will increase output of catfish farmers by 0.438 percent. This finding agrees with Hussain; Aroriode and Adedokun [15] and Adebayo [11] who reported that feeds ad a positive and significant relationship with catfish output.

Fingerlings quantity had a negative and significant coefficient at $1 \%$ probability level. This implies that one percent increase in the quantity of fingerlings above the recommended number will decrease the output of catfish farmers by 0.323 percent. This result conform to a priori expectation which states that over stocking of the pond can introduce unnecessary competitions and outbreak of diseases which will pose negative effects on fish growth and output. The findings contrast with Adulrahman et al. [14].

The estimated results of the inefficiency model revealed generally that a negative sign on a parameter means that the variable reduces technical inefficiency. The results show that all the technical inefficiency variable farming experience; educational 
status; amount borrowed; extension services and household size were statistically different from zero except age; cooperative membership and sex.

Farming experience had an estimated coefficient of $(-0.475)$ and this implies that farming experience was negatively related to the technical inefficiency of the catfish farmers and was statistically significant at $1 \%$ probability level. This means that a unit increase in the farmers farming experience will decrease their technical inefficiency by a magnitude of -0.475 . This finding conforms to a priori expectation and work by Asa and Obinaju [10]; who reported that farming experience is a spring board that exposes the farmer to understanding the intricacies and operational mechanics of the farm business thereby encouraging higher output.

The estimated coefficient of educational status was $(-0.583)$ and this means that educational status of the catfish farmers was negatively related to the technical inefficiency of the catfish farmers in the study area and statistically significant at $5 \%$ probability level. The implication is that a unit increase in the educational status of catfish farmer will decrease the technical inefficiency of the farmers by 0.583 . this finding conform to work by Ogwumba and Chukwuji [16]; who opined that educational level of catfish farmers had a positive and significant relationship with output in Akwa- Ibom State.

The estimated coefficient of amount borrowed was (0.784) and this implies that the amount of loan borrowed by catfish farmers was positively related to the technical inefficiency of the farmers and was statistically significant at $1 \%$ probability level. This means that a unit increase in the amount borrowed will increase the technical inefficiency of catfish farmers by a magnitude of 0.784 . The probable reason for this outcome is that majority of rural household borrowed to finance other family needs to the detriment of the farm business which the loan is meant to cater for. They use proceed of the farm on other family needs thereby starving the farm business of necessary requirements needed for improved productivity.

Extension contact had an estimated coefficient of $(-0.539)$ and this implies that the number of extension contact of the catfish farmers was negatively related to the technical inefficiency of the farmers and statistically significant at $1 \%$ level of probability. It indicates that a one unit increase in the number of extension contact to farmers will decrease the technical inefficiency of the catfish farmers by a magnitude of 0.539 . This finding is in agreement with Hussain; Aroriode and Adedokun [15] and Ogwumba and Chukwuji [16].

The estimated coefficient of household size was $(-0.728)$ and was statistically significant at $1 \%$ probability level. This implies that household size of catfish farmers was negatively related to the technical inefficiency of the farmers and that a one unit increase in the numbers of households of catfish farmers will decrease technical inefficiency by 0.728 . This finding conforms to a priori expectation and work Ohen and Abang [1].

\section{ConcLusion and ReCOMmEndations}

Based on the findings of the study; it can be concluded that vast opportunities exist in the catfish farming for employment generation especially for the teeming unemployed youths in the study area as the production of catfish is a highly profitable venture. The result of the technical efficiency analysis revealed that catfish farmers could still increase their production level by $43 \%$ through better use of available resources given the current state of technology. Based on the findings of the study; the following recommendations were suggested:

- Young unemployed youths should be encouraged to participate in the catfish business so as to generate employment and income.

- Extension workers should intensify and increase their organization of training; workshops and seminars for catfish farmers on improved methods and technology.

- The cost of farm implements and feeds should be subsidized to ease the risk of catfish farming.

- $\quad$ Financial institutions should develop methods such as time-operation loan progamme that target the gestation period of farm operation to ease the rate of loan repayment at moderate interest rates.

\section{REFERENCES}

1. Ohen, S. B., \& Abang, S. O. (2007). Economics of catfish farming in Rivers State, Nigeria. Academic Journal of Plant Sciences, 2(1), 56-59.

2. Bola, A. W. (2012). Poverty and income inequality among fish farming households in Oyo State, Nigeria. Medwell Agric. J., 7 (2): 100, 101.

3. Nwiro, E. (2012). Fish farming a lucrative business. Retrieved online July 2018 from http://www.thisdaylive.com/articles/fishfarming-a-lucrative-business/119253/.

4. Adekoya, B. B., \& Miller, J. W. (2004). Fish cage culture potential in Nigeria-An overview. National Cultures. Agriculture Focus, 1(5), 10.

5. Central Bank of Nigeria. (2006). Statistical bulletin. Annual report and statement of account. Abuja.

6. Adeogun, O.A., Alimi, T. \&., Adeyemo R. (2012). Status; cost and profitability of aquaculture enterprise in Nigeria: implications for food security. Int. journal of agricultural science. 2(1); 059-066. 
7. Federal Office of Statistics.(1996). Socio- economic development of Nigeria. Lagos.

8. National Population Commission. (2006). Population and housing census of the federal republic of Nigeria. Abuja.

9. Delta State. (2018). Main Facts. Retrieved from: http/www.deltastategov.ng.

10. Asa, U.A., \& Obinaju L.C. (2014). Economics of catfish production in Akwa-lbom State; Nigeria. Global journal of management and business research. 14(3): 23-27.

11. Adebayo, O.O. (2012). Determinants of extension service needs of catfish farmers in Oyo State; Nigeria: (a case study of Ido local government area). Journal of humanities and soc. Sci. 1(4); 54-58.

12. Coelli, T.J. (1995). Estimators and hypothesis test for a stochastic frontier function: a Monte Carlo analysis. Journal of productivity analysis, 6: 247-268.

13. Emokaro, C.O., \& Ekunwe P.A. (2009). Efficiency of resource use and elasticity of production among catfish farmers in Kaduna; Nigeria. Journal of applied science research; 5(7): $776-779$.

14. Abdulranhman, S., Ishaq, M.B., Abdullahi, M.Y., \& Ahmad, S.M. (2015). Impact of catfish production on poverty reduction in Okene local government area of Kogi State; Nigeria. Proceedings of the $29^{\text {th }}$ annual conference of FAMAN; Dutse.

15. Ogunbadejo, H., Aroriode, O. R., \& Adedokun, W. A. (2012). Productivity and technical efficiency of fish farming in lagos state. Continental Journal of Fisheries and Aquatic Sciences, 6(2), 8-15.

16. Asa, U. A., \& Solomon, V. A. (2015). Determinants of Catfish Production in Akwa lbom State, Nigeria. Journal of Basic and Applied Sciences, 11, 1-7. 